\title{
ANALISIS POLA MUSIM TANAM RUMPUT LAUT, Kappaphycus alvarezii MELALUI PENDEKATAN KESESUAIAN LAHAN DI NUSA PENIDA, BALI
}

\author{
I Nyoman Radiarta, Erlania, dan Rasidi \\ Pusat Penelitian dan Pengembangan Perikanan Budidaya \\ Jl. Ragunan 20, Pasar Minggu, Jakarta Selatan 12540 \\ E-mail: radiarta@yahoo.com
}

(Naskah diterima: 19 Maret 2014; Disetujui publikasi: 5 Juni 2014)

\begin{abstract}
ABSTRAK
Usaha budidaya rumput laut sangat dipengaruhi oleh lokasi dan iklim. Penyusunan pola musim tanam rumput laut yang benar dapat membantu dalam keberlanjutan usaha budidaya. Tujuan penelitian ini adalah untuk menganalisis pola musim tanam rumput laut, Kappaphycus alvarezii, berdasarkan pendekatan kesesuaian lahan pengembangan budidaya rumput laut di Nusa Penida, Bali. Data dikumpulkan pada bulan Mei dan September 2013. Kesesuaian lahan dianalisis secara spasial berdasarkan sistem informasi geografis, dengan memadukan antara faktor kualitas perairan dan sosialinfrastruktur. Hasil analisis menunjukkan bahwa bulan Mei merupakan bulan yang sesuai untuk K. alvarezii dibandingkan dengan bulan September. Kawasan Pulau Nusa Lembongan dan Nusa Ceningan merupakan kawasan yang lebih sensitif terhadap perubahan kondisi perairan. Hasil penelitian ini dapat dijadikan acuan dalam penyusunan strategi musim tanam di Nusa Penida.
\end{abstract}

KATA KUNCl: kesesuaian lahan, rumput laut, musim tanam, analisis spasial, Nusa Penida

ABSTRACT: Analysis of cultivation periods for seaweed, Kappaphycus alvarezii, aquaculture through suitability site asessment aproach in Nusa Penida, Bali. By: I Nyoman Radiarta, Erlania, and Rasidi

Seaweed cultivation is greatly influenced by the location and climate variability. Developing seaweed cultivation periods could assist in the sustainability of seaweed aquaculture. The purpose of this study was to analyze the periods of seaweed, Kappaphycus alvarezii, aquaculture development based on suitability site analysis approach in Nusa Penida, Bali. Data were collected in May and September 2013. Suitability site for seaweed aquaculture was spatially analyzed using geographic information system based on water quality and socio-infrastructure factors. The results show that May is the best month for cultivating $\boldsymbol{K}$. alvarezii compared with September. Nusa Lembongan and Nusa Ceningan Islands were indicated more sensitive area in term of change in water quality condition compared with Nusa Penida Island. The results of this study can be used as a reference for developing a strategic seaweed cultivation periods in Nusa Penida.

KEYWORDS: suitability sites, seaweeds, cultivation period, spatial analysis, Nusa Penida 


\section{PENDAHULUAN}

Rumput laut penghasil karaginan (karaginofit), misalnya Kappaphycus alvarezii dan Eucheuma denticulatum, telah banyak dibudidayakan di perairan Indonesia dengan menggunakan berbagai jenis metode budidaya, di antaranya metode lepas dasar, rakit apung, rawai (long line), dan metode jalur (Parenrengi et al., 2011). Usaha budidaya rumput laut banyak diminati masyarakat dengan pertimbangan teknologi budidaya yang mudah, waktu pemeliharaan cukup singkat, dan harga pasar yang kompetitif. Melalui program minapolitan dan industrialisasi, Kementerian Kelautan dan Perikanan Indonesia telah menetapkan rumput laut sebagai satu komoditas unggulan perikanan. Sejak dicanangkannya kedua program tersebut, produksi rumput laut menunjukkan peningkatan yang sangat signifikan yaitu dari sekitar 223 ribu ton di tahun 2002 menjadi 4,5 juta ton di tahun 2011 atau meningkat sebesar 1.900\% (DJPB, 2012). Rumput laut yang diproduksi tersebut masih dapat ditingkatkan, karena lahan budidaya laut yang tersedia di perairan Indonesia baru dimanfaatkan sekitar 1\% (KKP, 2011).

Nusa Penida merupakan salah satu wilayah kecamatan di Kabupaten Klungkung, Bali. Wilayah kecamatan ini terdiri atas tiga pulau besar yaitu Pulau Nusa Penida, Nusa Lembongan, dan Nusa Ceningan. Budidaya rumput laut telah berkembang hampir menyebar sepanjang pantai di ketiga pulau tersebut meliputi Desa Suana, Batununggul, Kutampi, Ped, Toyopakeh, Jungutbatu, dan Lembongan. Kawasan Nusa Penida telah ditetapkan sebagai kawasan pembangunan kelautan dan perikanan yang berbasis ekonomi biru (KKP, 2014). Beberapa aktivitas yang menjadi perhatian di kawasan ini di antaranya perikanan (budidaya dan tangkap), wisata bahari, dan kawasan konservasi. Budidaya laut yang banyak berkembang di kawasan Nusa Penida adalah budidaya rumput laut. Jenis yang umum dikembangkan adalah $K$. alvarezii dan E. denticulatum. Kedua jenis rumput laut ini dikembangkan sesuai dengan kondisi lingkungan perairan dan iklim, terutama jenis $K$. alvarezii yang sangat peka terhadap perubahan lingkungan dibandingkan dengan $E$. denticulatum yang dapat dibudidayakan sepanjang tahun (Parenrengi et al., 2011)

Perencanaan dan pengelolaan sumberdaya lahan untuk kegiatan budidaya perikanan harus didukung oleh ketersediaan data dan informasi tentang kesesuaian lahan untuk komoditas unggulan yang akurat dan terbaru (up to date). Kajian kesesuaian lahan dapat dilakukan dengan memperhatikan beberapa faktor penting di antaranya lingkungan perairan (parameter fisika, kimia, dan biologi), sosial-ekonomi, dan infrastruktur (fasilitas penunjang). Ketersediaan data potensi ini dapat membantu pengambil keputusan dalam rangka memanfaatkan dan menghindari (meminimalkan) konflik kepentingan, serta menghindari penurunan kualitas lingkungan demi keberlanjutan usaha budidaya laut (GESAMP, 2001).

Pola/kalender musim tanam sangat diperlukan guna mendukung keberlanjutan usaha budidaya rumput laut. Sejauh ini, penyusunan kalender musim tanam umumnya disusun dengan memperhatikan musim ice-ice, musim hujan, musim kemarau, musim gulma (lumut), dan pertumbuhan kerdil (Parenrengi et al., 2011 ). Pemanfaatan data iklim dapat juga dijadikan acuan dalam penyusunan musim tanam rumput laut (Radiarta et al., 2013). Data iklim yang perlu diperhatikan meliputi: suhu udara, kecepatan angin, curah hujan, dan lama penyinaran matahari. Selain pendekatan iklim, pendekatan kondisi kualitas perairan dalam kurun waktu yang berkelanjutan dan dianalisis secara spasial dalam bentuk kesesuaian lahan dapat dijadikan acuan juga dalam penyusunan pola musim tanam rumput laut. Penelitian ini bertujuan untuk menganalisis pola musim tanam rumput laut $K$. alvarezii berdasarkan pendekatan kesesuaian lahan pengembangan budidaya rumput laut di Nusa Penida, Bali. Hasil dari penelitian ini diharapkan dapat memberikan rekomendasi untuk mendukung program ekonomi biru dalam rangka perkembangan usaha budidaya rumput laut dan peningkatan produksi perikanan budidaya di Nusa Penida secara khusus dan di Indonesia secara umum.

\section{BAHAN DAN METODE}

Penelitian ini dilaksanakan pada bulan Mei dan September 2013 di Nusa Penida Kabupaten Klungkung, Bali, yang terbentang pada posisi $115^{\circ} 25^{\prime}-115^{\circ} 37^{\prime}$ Bujur Timur dan $8^{\circ} 39^{\prime}-8^{\circ} 45^{\prime}$ Lintang Selatan (Gambar 1). Lokasi penelitian merupakan kawasan potensial untuk pengembangan budidaya rumput laut terutama pada area pasang surut (rataan terumbu), dan umumnya terbentang pada pantai utara meliputi Pulau Nusa Penida, Pulau 
Nusa Lembongan, dan Pulau Nusa Ceningan (DPPK, 2001).

\section{Pengumpulan Data}

Data kualitas perairan dikumpulkan pada dua bulan yang berbeda yaitu bulan Mei dan September 2013. Pengumpulan data pada dua bulan yang berbeda ini diharapkan dapat memberikan gambaran umum tentang karakteristik kondisi perairan yang dapat memengaruhi pola musim tanam rumput laut (DPPK, 2001). Sebanyak 58 stasiun pengamatan kualitas perairan disebar secara acak terstruktur di lokasi penelitian (Morain, 1999); sehingga dapat mewakili karakteristik wilayah yang disurvai (Gambar 1). Pengukuran kualitas air dilakukan di lapangan dengan menggunakan YSI Profesional Plus, dan dianalisis di laboratorium Biotrop, Bogor. Metode pengambilan, preservasi, dan analisis contoh air mengacu pada metode standar APHA (2005).
Ketersediaan peta dasar sangat diperlukan untuk melakukan analisis kesesuaian lahan. Peta dasar yang digunakan bersumber dari Rupa Bumi Indonesia (cetakan dan digital) skala 1:25.000 dengan nomor peta 1707-324 (Sebuluh Kangin); 1707-342 (Toyopakeh), 1807-113 (Tanglad) dan 1807-131 (Sampalan); Lingkungan Pantai Indonesia skala 1:50.000 nomor peta 1707-11 (Gianyar) keluaran Badan Informasi Geospasial (BIG), citra satelit World View-2 tanggal perekaman 15 September 2012 dan 26 Oktober 2012 dan ALOS AVNIR-2 tanggal perekaman 3 April 2009. Berdasarkan data tersebut, diekstrak tema utama sebagai peta dasar meliputi: garis pantai, sungai, sebaran penduduk, kawasan wisata, ekosistem pesisir, dan infrastruktur pendukung lainnya, serta beberapa tipe tutupan lahan. Selain peta dasar, data sekunder lainnya yang dikumpulkan adalah data meteorologi dan klimatologi diperoleh dari Badan Meteorologi, Klimatologi, dan Geofisika (BMKG) wilayah 3 Denpasar.

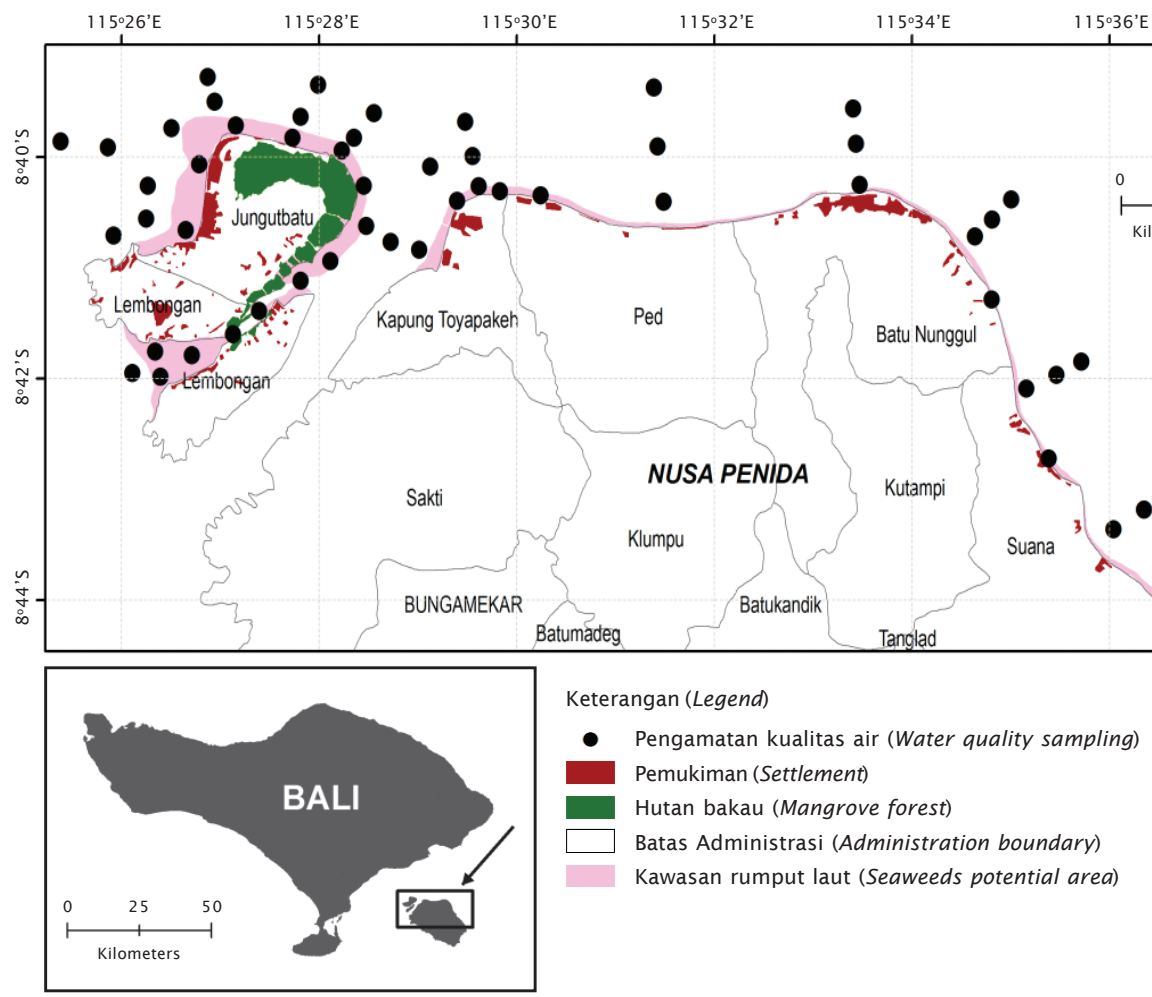

Gambar 1. Peta lokasi penelitian di Nusa Penida, Kabupaten Klungkung yang menunjukkan sebaran titik pengamatan kualitas perairan

Figure 1. Map of the study area in Nusa Penida, Klungkung Regency, showing the location of water quality sampling stations 


\section{Analisis Kesesuaian Lahan}

Tahapan analisis kesesuaian lahan untuk pengembangan budidaya rumput laut yang digunakan dalam penelitian ini mengikuti Radiarta et al. (2012). Penentuan skor untuk masing-masing parameter berdasarkan efek dari parameter tersebut bagi budidaya rumput laut, $K$. alvarezii. Penelitian ini menggunakan skor 1-4; skor 4 adalah sangat sesuai, sedangkan 1 adalah tidak sesuai bagi kegiatan budidaya rumput laut (Tabel 1). Tingkat kesesuaian lahan masing-masing parameter mengacu pada Tiensongrusmee (1990), Mubarak et al. (1990), Sulistijo \& Nontji (1995), KLH (2004), dan Radiarta et al. (2008).

Model kesesuaian lahan untuk budidaya rumput laut di Nusa Penida disusun berdasarkan model hirarki (Malczewski, 2000), dan bobot dari masing-masing peubah ditentukan dengan pair-wise comparison, yang merupakan bagian dari proses pengambilan keputusan yang dikenal dengan metode analytical hierarchy process (AHP; Saaty, 1977) (Gambar 2).

Berdasarkan skor dan bobot yang diperoleh, kemudian analisis spasial kesesuaian lahan dilakukan dengan metode weighted linear combination (Malczewski, 1999) yang terdapat dalam perangkat lunak ArcGIS versi 10 .

\section{HASIL DAN BAHASAN}

\section{Analisis Kesesuaian Lahan Budidaya Rumput Laut}

Keberhasilan dalam budidaya rumput laut dapat dipengaruhi oleh beberapa aspek di antaranya karakteristik lokasi budidaya yang berhubungan dengan kesesuaian lahan (Parenrengi et al., 2011). Kesesuaian lahan dalam penelitian ini dianalisis berdasarkan faktor kondisi kualitas perairan dan sosial-infrastruktur. Distribusi spasial tingkat kesesuaian lahan pengembangan budidaya rumput laut, K. alvarezii, di Nusa Penida disajikan pada

Tabel 1. Tingkat kesesuaian parameter kualitas perairan dan sosial-infrastruktur untuk budidaya rumput laut di Nusa Penida, Kabupaten Klungkung, Bali

Table 1. Water quality and socio-infrastructure factors requirement and suitability scores for seaweed aquaculture in Nusa Penida, Klungkung Regency, Bali

\begin{tabular}{|c|c|c|c|c|c|}
\hline $\begin{array}{c}\text { Peubah } \\
\text { Parameters }\end{array}$ & $\begin{array}{c}\text { Satuan } \\
\text { Unit }\end{array}$ & $\begin{array}{l}\text { Sangat } \\
\text { sesuai } \\
\text { Most } \\
\text { suitable }\end{array}$ & $\begin{array}{l}\text { Sesuai } \\
\text { Suitable }\end{array}$ & $\begin{array}{c}\text { Cukup } \\
\text { sesuai } \\
\text { Marginally } \\
\text { suitable }\end{array}$ & $\begin{array}{c}\text { Tidak } \\
\text { sesuai } \\
\text { Not } \\
\text { suitable }\end{array}$ \\
\hline \multicolumn{6}{|l|}{$\begin{array}{l}\text { Kualitas air } \\
\text { Water quality }\end{array}$} \\
\hline $\begin{array}{l}\text { Suhu air } \\
\text { Water temperature }\end{array}$ & ${ }^{\circ} \mathrm{C}$ & $28-30$ & $\begin{array}{l}30-32 \\
27-28\end{array}$ & $32-35$ & $<27 ;>35$ \\
\hline $\begin{array}{l}\text { Oksigen terlarut } \\
\text { Dissolved oxygen }\end{array}$ & $\mathrm{mg} / \mathrm{L}$ & $>5$ & $3-5$ & $1-3$ & $<1$ \\
\hline $\begin{array}{l}\text { Salinitas } \\
\text { Salinity }\end{array}$ & $\mathrm{ppt}$ & $32-34$ & $28-32$ & $25-28$ & $\begin{array}{l}<25 \text { atau }>34 \\
<25 \text { or }>34\end{array}$ \\
\hline $\mathrm{pH}$ & & $7.5-8.5$ & $\begin{array}{l}4-7.5 \\
8.5-10\end{array}$ & $2-4 ; 10-11$ & $<2 ;>11$ \\
\hline $\begin{array}{l}\text { Nitrat } \\
\text { Nitrate }\end{array}$ & $\mathrm{mg} / \mathrm{L}$ & $0.1-3.5$ & $0.01-0.1$ & $0.008-0.01$ & $\begin{array}{c}<0.008 \text { atau }>3.5 \\
<0.008 \text { or }>3.5\end{array}$ \\
\hline \multicolumn{6}{|l|}{$\begin{array}{l}\text { Sosial-infrast rukt ur } \\
\text { Socio-infrast ruct ure }\end{array}$} \\
\hline $\begin{array}{l}\text { Jarak ke pe mukiman } \\
\text { Distance to settlement }\end{array}$ & $\mathrm{m}$ & $<1,000$ & $1,000-2,000$ & $2,000-3,000$ & $>3,000$ \\
\hline $\begin{array}{l}\text { Jarak ke pelabuhan } \\
\text { Distance to harbor }\end{array}$ & $\mathrm{m}$ & $>1,000$ & 700-1,000 & $500-700$ & $<500$ \\
\hline
\end{tabular}




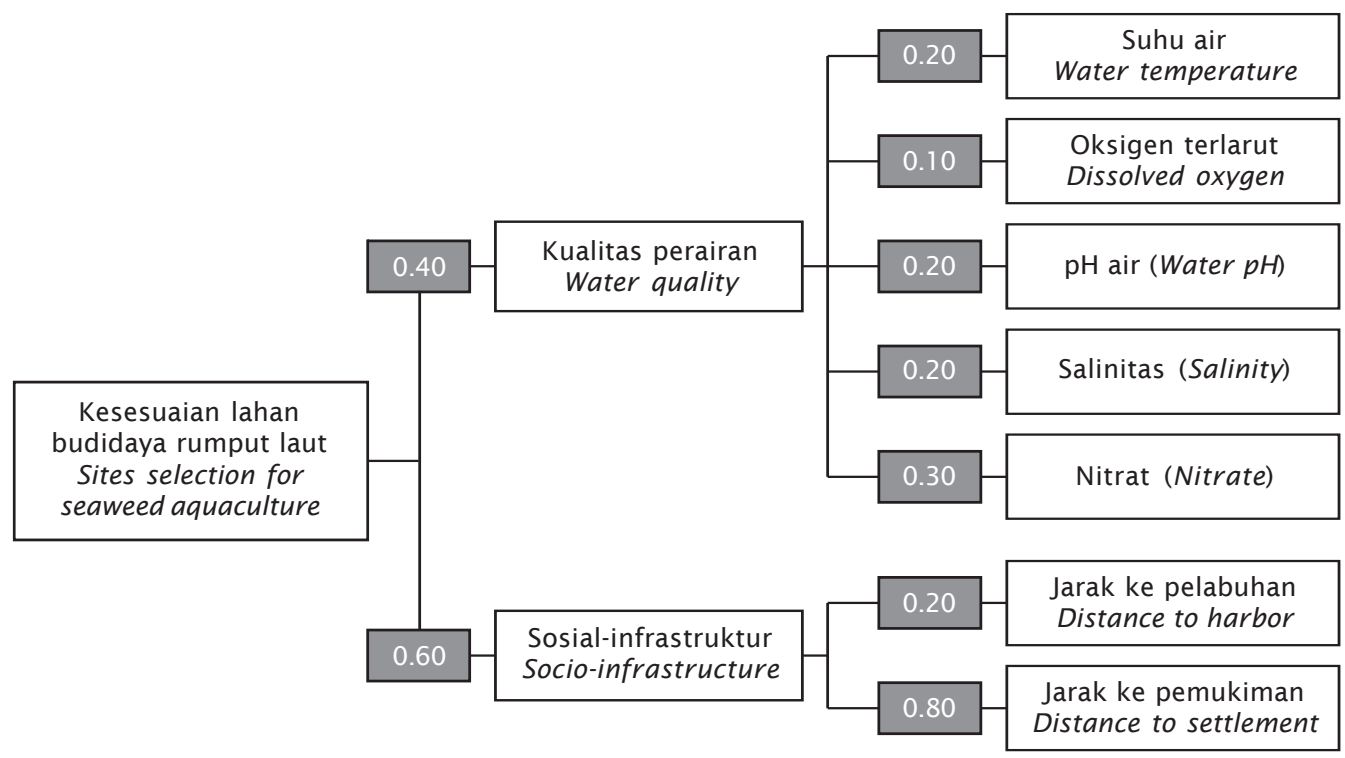

Gambar 2. Model hirarki kesesuaian Iahan budidaya rumput laut di Nusa Penida, Kabupaten Klungkung, Bali. Angka menunjukkan bobot dari masing-masing parameter/faktor

Figure 2. Hierarchical model for selecting suitable sites for seaweed aquaculture in Nusa Penida, Klungkung Regency, Bali. Number indicate weight for parameter/factors

Gambar 3. Tabel 2 menampilkan luasan kawasan pengembangan budidaya rumput laut berdasarkan tingkat kesesuaian Iahan pada bulan Mei dan September.

Kondisi kesesuaian lahan di lokasi penelitian sangat dipengaruhi oleh karakteristik kualitas perairan. Hal ini tergambar secara jelas pada tingkat kesesuaian lahan untuk dua bulan yang berbeda yaitu bulan Mei dan September (Gambar 3A; Tabel 2). Bulan Mei dapat dikatakan bulan yang baik untuk budidaya rumput laut, K. alvarezii. Dari total area potensial sebesar 583 ha, area dengan kategori sangat sesuai ditemukan sebesar 88 ha. Sekitar 437 ha masuk dalam kategori sesuai dan sisanya masuk dalam cukup sesuai (Tabel 2). Area sekitar Pulau Nusa Lembongan dan Nusa Ceningan umumnya masuk kategori sesuai, sedangkan Pulau Nusa Penida didominasi oleh kategori sangat sesuai (Gambar 3a). Analisis faktor kualitas air bulan September menunjukkan bulan yang kurang baik untuk budidaya rumput laut, $K$. alvarezii. Kawasan dengan kategori sangat sesuai hanya ditemukan sebesar 3 ha. Sekitar 265 ha masuk dalam kategori sesuai dan 315 ha masuk dalam cukup sesuai (Tabel 2). Area sekitar Pulau Nusa Lembongan dan Ceningan menunjukkan kawasan yang sensitif terhadap perubahan kondisi kualitas perairan, dan secara otomatis akan berpengaruh terhadap perkembangan $K$. alvarezii yang dibudidayakan.

Dukungan sosial-infrastruktur yang meliputi kawasan pemukiman dan pelabuhan sangat memengaruhi keberlangsungan usaha budidaya rumput laut (Luxton, 1999). Jarak pemukiman yang relatif dekat dengan lokasi budidaya akan memudahkan pembudidaya dalam melakukan aktivitas sehari-hari seperti penyiapan, pemeliharaan, dan pemanenan rumput laut. Dukungan infrastruktur berupa pelabuhan laut juga tersedia cukup baik di lokasi penelitian. Secara umum faktor sosialinfrastruktur bukan merupakan penghambat perkembangan budidaya rumput laut. Dari total potensial area yang tersedia, sekitar 500 ha masuk dalam kategori sangat sesuai untuk pengembangan budidaya rumput laut (Gambar 3B; Tabel 2).

Dengan menggabungkan seluruh faktor, akhirnya diperoleh klasifikasi kesesuaian lahan untuk budidaya rumput K. alvarezii (Gambar 3C). Hasil analisis pada dua bulan yang berbeda menunjukkan bahwa bulan Mei sangat mendukung aktivitas budidaya yang menyediakan kawasan seluas 463 ha dengan kategori sangat sesuai (Tabel 2). Kawasan yang sangat sesuai 


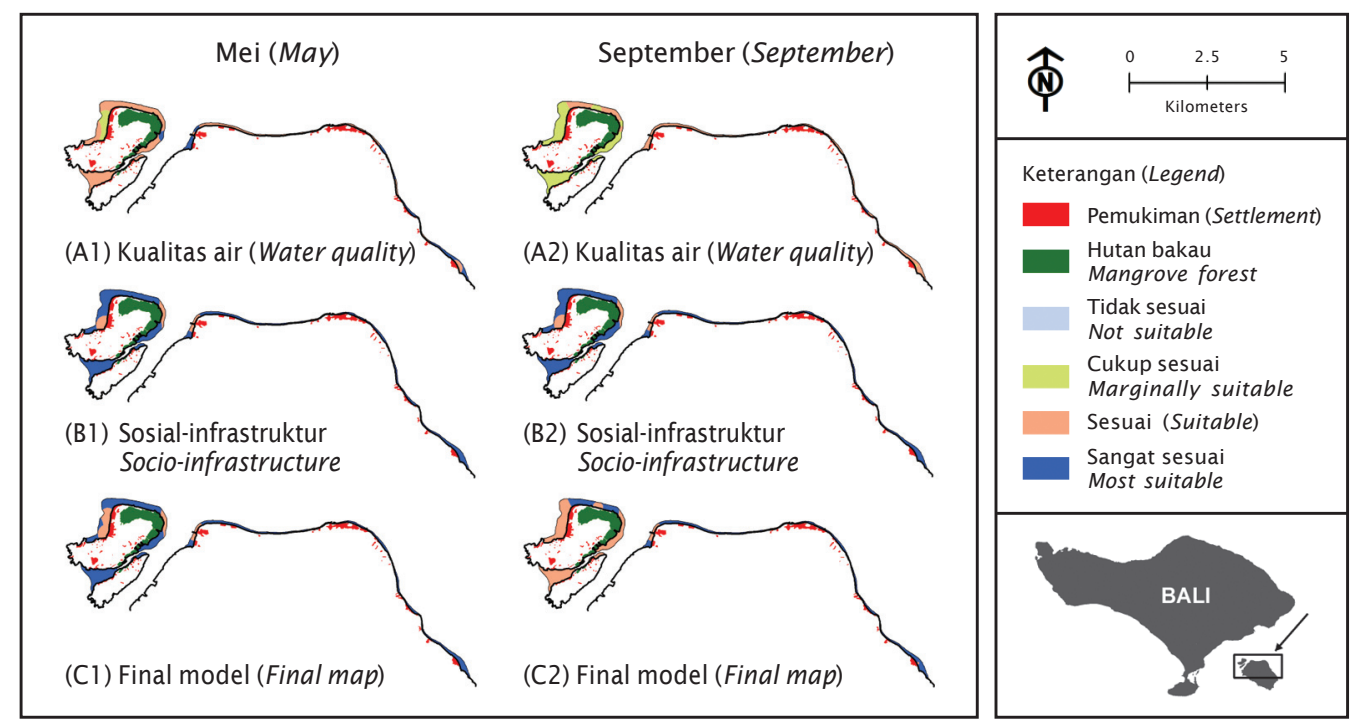

Gambar 3. Peta tingkat kesesuaian lahan pengembangan budidaya rumput laut, K. alvarezii, di Nusa Penida, Kabupaten Klungkung, Bali, berdasarkan dua waktu pengamatan yang berbeda untuk faktor kualitas perairan (A), faktor sosial-infrastruktur (B), dan peta akhir tingkat kesesuaian lahan (C)

Figure 3. Suitability sites maps for seaweed, K. alvarezii, aquaculture development in Nusa Penida, Klungkung Regency, Bali, based on two different observation times for (A) water quality, (B) socio-infrastructure, and (C) final suitability model

hampir ditemukan di seluruh lokasi penelitian kecuali di depan Pulau Nusa Lembongan, sekitar kawasan pariwisata dan kawasan hutan mangrove (Gambar 3C). Sedangkan pada bulan September kawasan yang masuk kategori sangat sesuai hanya sekitar 231 ha. Kawasan ini umumnya tersebar di Pulau Nusa Penida (Gambar 3C).

Hasil analisis kesesuaian lahan budidaya rumput laut untuk dua bulan yang berbeda yaitu bulan Mei dan September, sangat jelas menunjukkan bahwa bulan Mei merupakan bulan yang baik untuk budidaya rumput laut, K. alvarezii, dibandingkan dengan bulan September. Dari analisis ini dapat dikatakan bahwa wilayah pengembangan rumput laut di Pulau Nusa Lembongan dan Nusa Ceningan lebih sensitif terhadap perubahan lingkungan perairan sehingga sangat memengaruhi aktivitas budidaya rumput laut yang berkembang di kawasan tersebut. Analisis kesesuaian lahan yang dihasilkan dalam penelitian ini dapat dijadikan sebagai satu pendekatan dalam penyusunan pola musim tanam yang baik untuk budidaya rumput laut di Nusa Penida. Penyusunan pola musim tanam ini sangat penting guna mendukung keberlanjutan usaha budidaya dan meningkatkan produktivitasnya (Parenrengi et al., 2011; Radiarta et al., 2013).

Pengumpulan dan analisis data dilakukan paling sedikit empat kali dalam setahun yang dapat mewakili setiap musim untuk memperoleh hasil yang lebih baik dan komprehensif. Ketersediaan data yang kontinu tersebut dapat digunakan untuk menyusun pola musim tanam yang lebih baik, selain itu, dapat juga dilakukan zonasi secara spesifik lokasi pengembangan budidaya rumput laut untuk jenis rumput laut yang berkembang di lokasi penelitian yaitu $E$. spinosum dan K. alvarezii (E. cottonii).

\section{Pendekatan Pola Musim Tanam}

Karakteristik lingkungan perairan seperti suhu, salinitas, cahaya, dan ketersediaan nutrien sangat memengaruhi kandungan nutrien dalam rumput laut (Marinho-Soriano et al., 2006; Diharmi et al., 2011). Umumnya kondisi perairan tersebut sangat bervariasi bergantung pada musim dan perubahan kondisi ekologi perairan yang dapat memengaruhi kandungan nutrien dalam perairan (Handa et al., 2013). Faktor musim sangat dipengaruhi oleh kondisi 
Tabel 2. Luasan wilayah (ha) berdasarkan tingkat kesesuaian untuk pengembangan budidaya rumput laut, K. alvarezii, di Nusa Penida, Kabupaten Klungkung, Bali. Total area analisis adalah 583 ha

Table 2. Total suitable area (ha) for seaweed, K. alvarezii, aquaculture development in Nusa Penida, Klungkung Regency, Bali. Total area analysis is 583 ha

\begin{tabular}{|c|c|c|c|c|}
\hline \multirow{2}{*}{$\begin{array}{l}\text { Peubah } \\
\text { Parameters }\end{array}$} & \multicolumn{4}{|c|}{ Luasan (Area) (ha) } \\
\hline & $\begin{array}{l}\text { Sangat sesuai } \\
\text { Most suitable }\end{array}$ & $\begin{array}{l}\text { Sesuai } \\
\text { Suitable }\end{array}$ & $\begin{array}{l}\text { Cukup sesuai } \\
\text { Moderately suitable }\end{array}$ & $\begin{array}{l}\text { Tidak sesuai } \\
\text { Not suit able }\end{array}$ \\
\hline \multicolumn{5}{|l|}{$\begin{array}{l}\text { Model Mei } \\
\text { May model }\end{array}$} \\
\hline $\begin{array}{l}\text { Kualitas perairan } \\
\text { Water quality }\end{array}$ & 88 & 437 & 58 & 0 \\
\hline $\begin{array}{l}\text { Sosial-infrastruktur } \\
\text { Socio-infrastructure }\end{array}$ & 500 & 83 & 0 & 0 \\
\hline $\begin{array}{l}\text { Kesesuaian lahan } \\
\text { budidaya rumput laut } \\
\text { Suitability site for } \\
\text { seaweed aquaculture }\end{array}$ & 463 & 120 & 0 & 0 \\
\hline \multicolumn{5}{|l|}{$\begin{array}{l}\text { Model Sept ember } \\
\text { Sept ember model }\end{array}$} \\
\hline $\begin{array}{l}\text { Kualitas perairan } \\
\text { Water quality }\end{array}$ & 3 & 265 & 315 & 0 \\
\hline $\begin{array}{l}\text { Sosial-infrastruktur } \\
\text { Socio-infrastructure }\end{array}$ & 500 & 83 & 0 & 0 \\
\hline $\begin{array}{l}\text { Ke se suaian lahan } \\
\text { budiday a rumput laut } \\
\text { Suitability site for } \\
\text { seaweed aquacult ure }\end{array}$ & 231 & 352 & 0 & 0 \\
\hline
\end{tabular}

iklim (meteorologi dan klimatologi), dan belakangan ini memiliki tingkat variabilitas/ fluktuasi yang cukup tinggi. Hal ini dapat memengaruhi produktivitas rumput laut yang dibudidayakan (Radiarta et al., 2013). MarinhoSoriano et al. (2006) telah melakukan kajian tentang pengaruh variasi musim terhadap komposisi kimia rumput laut, dan menyimpulkan bahwa terdapat hubungan yang erat antara kandungan karbohidrat dan nitrogen rumput laut dengan parameter iklim (curah hujan dan sinar matahari), suhu perairan, dan salinitas. Selain variasi musim, lokasi juga sangat menentukan kandungan kimia dari rumput laut (Diharmi et al., 2011 ). Hal ini menunjukkan bahwa dalam satu kawasan budidaya rumput laut, variasi musim, dan karakteristik lokasi pengembangan (kesesuaian lahan) merupakan dua faktor penting yang perlu diperhatikan guna mendukung keberhasilan budidaya rumput laut.

Penentuan pola atau kalendar musim tanam rumput laut umumnya dilakukan melalui pemantauan budidaya rumput laut secara berkala dan berkelanjutan meliputi beberapa parameter kunci permasalahan yang dihadapi oleh pembudidaya (Parenrengi et al., 2011). Permasalahan yang timbul tersebut dijadikan acuan untuk menyusun kalendar musim tanam. Permasalahan yang umum dipantau meliputi musim penyakit, musim hujan (angin, ombak besar), musim kemarau, musim gulma, dan musim pertumbuhan kerdil; dan permasalahan tersebut tentunya akan bervariasi antara lokasi. Secara global pemanfaatan data iklim dapat juga dijadikan acuan dalam penyusunan kalendar musim tanam (Radiarta et al., 2013). Parameter iklim yang umum digunakan meli- 
puti suhu udara, kecepatan angin, penyinaran matahari, dan curah hujan. Peran penting iklim untuk kajian perikanan budidaya telah dibahas secara komprehensif oleh Kapetsky (2000). Selain pendekatan budidaya dan iklim yang sering digunakan untuk penentuan pola musim tanam rumput laut, pendekatan kesesuaian lahan juga dapat dijadikan sebagai alternatif analisis. Pendekatan kesesuaian lahan umumnya dilakukan dengan mempertimbangkan kondisi lingkungan perairan. Sedangkan data meteorologi dan klimatologi dapat digunakan sebagai data pendukung untuk memperjelas karakteristik lahan pada kawasan pengembangan.

Hasil analisis data meteorologi dan klimatologi yang diperoleh dari BMKG wilayah 3 Denpasar tahun 2005-2010 disajikan pada Gambar 4. Suhu udara menunjukkan fluktuasi setiap tahunnya yaitu suhu maksimum ditemukan sekitar bulan November-Januari, dan minimum sekitar bulan Juli-September. Data suhu udara ini dapat dijadikan sebagai data proxy suhu perairan, jika dalam satu kawasan data suhu perairan tidak tersedia. Fluktuasi suhu udara ini secara umum berbanding terbalik dengan penyinaran matahari (Gambar 4). Ketersediaan cahaya matahari ini sangat penting bagi pertumbuhan rumput laut yang dibudidayakan. Penyinaran matahari yang maksimum dan diikuti dengan kondisi suhu udara yang sesuai akan mendukung pertumbuhan rumput laut. Penelitian tentang pertumbuhan rumput laut pada kedalaman yang berbeda yang dilakukan di Norway (Handa et al., 2013), menunjukkan rumput laut tumbuh secara maksimal pada kedalaman $2 \mathrm{~m}$ dan $5 \mathrm{~m}$ dibandingkan dengan kedalaman $8 \mathrm{~m}$. Hal ini berhubungan erat dengan ketersediaan cahaya untuk fotosintesis yang dilakukan oleh rumput laut.

Kecepatan angin merupakan parameter cuaca lainnya yang sangat penting karena dapat memengaruhi kondisi gelombang dan kecepatan arus permukaan perairan, dan secara tidak langsung akan memengaruhi media

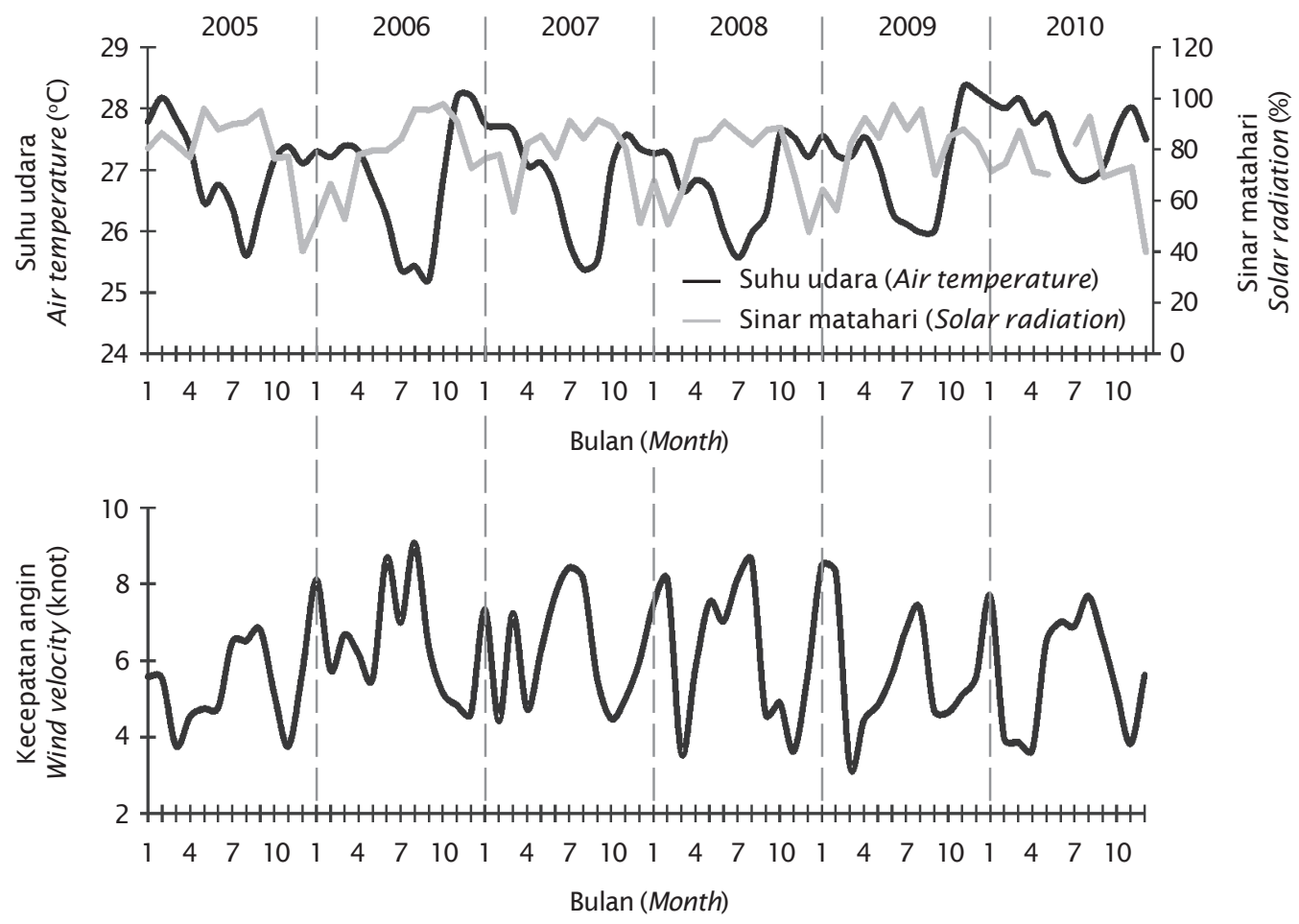

Gambar 4. Data bulanan meteorologi dan klimatologi hasil pemantauan dari stasiun BMKG Denpasar tahun 2005-2010

Figure 4. Monthly meteorology and climatology data obtained from Denpasar meteorology and klimatology station in 2005-2010 
budidaya rumput laut yang digunakan. Hasil pemantauan kecepatan angin menunjukkan bahwa kecepatan angin memiliki pola yang sama setiap tahunnya. Kecepatan angin maksimum ditemukan sekitar bulan Juli-September dan Desember-Januari, sedangkan kecepatan minimum sekitar bulan Februari-Mei (Gambar 4).

Berdasarkan data meteorologi dan klimatologi menunjukkan bahwa secara umum kisaran bulan yang baik untuk budidaya rumput laut di lokasi penelitian adalah antara bulan Februari-Juni. Pada bulan tersebut didukung dengan kondisi penyinaran matahari yang optimal, suhu udara yang tidak terlalu panas, dan kecepatan angin yang minimum. Pendekatan data meteorologi dan klimatologi ini sangat mendukung dengan hasil yang diperoleh dari analisis kesesuaian Iahan budidaya rumput laut. Hasil analisis bulan Mei menunjukkan bulan yang optimum untuk budidaya rumput laut jenis $K$. alvarezii dibandingkan dengan bulan September (Gambar 3 dan 4).

\section{Keragaan Budidaya Rumput Laut}

Kecamatan Nusa Penida memiliki panjang garis pantai sekitar 83,50 km; dengan karakteristik pantai tergolong landai sampai curam. Pesisir sepanjang pantai bagian Utara berupa lahan datar dengan kemiringan 0\%-3\% dari ketinggian lahan 0-268 $\mathrm{m}$ di atas permukaan laut (dpl) dan semakin ke Selatan kemiringan lerengnya semakin bergelombang (DPPK, 2001; Welly et al., 2011 ). Berdasarkan karakteristik lahan tersebut, kegiatan budidaya rumput laut hanya ditemukan di pesisir bagian Utara yang memanfaatkan kawasan pasang surut (rataan terumbu) dengan kedalaman antara 0,5-3,0 m.

Sesuai dengan kondisi kawasan pesisir, rumput laut yang dibudidayakan di Nusa Penida menggunakan metode tali lepas dasar atau lebih dikenal dengan metode patok. Rumput laut yang dominan dibudidayakan adalah jenis E. denticulatum (nama populernya E. spinosum). Karena adanya permintaan pasar yang besar dan harga yang cukup tinggi, $K$. alvarezii (nama populernya E. cottonii) juga telah dibudidayakan di Nusa Penida, namun produksinya masih jauh di bawah $E$. denticulatum (DPPK, 2001). Pola usaha yang dilakukan pada rumput laut bersifat budidaya dengan satu jenis saja atau monoculture. Kegiatan budidaya dilakukan pada suatu hamparan budidaya dengan kepemilikan secara individual. Kepemilikan lahan budidaya di Nusa Penida diukur dengan satuan are (10 $\mathrm{m} \times 10 \mathrm{~m}$ ). Satu rumah tangga pembudidaya (RTP) minimal memiliki 3 are, rata-rata RTP memiliki sepuluh petak areal budidaya. Masingmasing pembudidaya memiliki luas lahan yang berbeda-beda, makin kuat status ekonomi seorang pembudidaya, semakin luas areal budidaya yang dimilikinya. Berdasarkan luasan lahan yang dimiliki dapat dibedakan pembudidaya skala kecil (luas lahan 127,71 $\mathrm{m}^{2}$ ), skala sedang $\left(378,80 \mathrm{~m}^{2}\right)$, dan skala besar $\left(818,75 \mathrm{~m}^{2}\right)$ (Sobari, 1993).

Perkembangan budidaya rumput laut di Nusa Penida mengalami fluktuasi produksi, hal ini disebabkan karena: (1) adanya perubahan musim dan cuaca memengaruhi kondisi oseanografi perairan (fisik dan kimia perairan) sehingga dapat berdampak pada hasil budidaya rumput laut, dan (2) adanya arus panas yang melintas di perairan Nusa Penida, terkadang juga dapat menyebabkan penyakit pada rumput laut (ice-ice) sehingga menyebabkan gagal panen (DPPK, 2001). Adanya perubahan iklim tersebut dapat memengaruhi kondisi perairan sehingga secara tidak langsung dapat berpengaruh terhadap kelangsungan budidaya rumput laut $K$. alvarezii. Radiarta et al. (2013) secara nyata menggambarkan bagaimana hubungan antara faktor iklim (lokal dan global) terhadap pola musim tanam rumput laut di kawasan Teluk Gerupuk, Lombok. Berdasarkan hasil diskusi dengan pembudidaya setempat, menunjukkan bahwa adanya ketidakpastian atau perubahan iklim pada bulan-bulan tertentu sangat memengaruhi produktivitas rumput laut yang dibudidayakan.

\section{Perspektif Pengembangan Budidaya Rumput Laut Berdasarkan Siklus Musim Tanam}

Produktivitas budidaya rumput laut sangat dipengaruhi oleh musim dan lokasi (Parenrengi et al., 2011). Perubahan iklim dapat memengaruhi karakteristik fisik dan kimia perairan sehingga dapat berdampak dengan timbulnya penyakit ice-ice. Penyakit ini merupakan kendala yang paling sering terjadi dan sangat ditakuti oleh pembudidaya rumput laut. Dengan mengetahui karakteristik lokasi (kesesuaian lahan) pengembangan secara baik tentunya dapat meminimalkan dampak negatif terhadap budidaya rumput laut dan memaksimalkan produksinya.

Budidaya rumput laut yang berkembang di kawasan Nusa Penida adalah K. alvarezii dan 
E. denticulatum. Kedua jenis ini memiliki kerentanan terhadap perubahan kondisi lingkungan yang cukup berbeda. Jenis $E$. denticulatum umumnya lebih tahan terhadap perubahan lingkungan (suhu dan salinitas) dibandingkan dengan jenis $K$. alvarezii (Parenrengi et al., 2011). Berdasarkan tingkat kerentanan dari kedua jenis rumput laut tersebut dan hasil analisis kesesuaian lahan dalam penelitian ini dapat direkomendasikan bahwa jenis $E$. denticulatum lebih baik dibudidayakan di kawasan pesisir Pulau Nusa Ceningan dan Nusa Lembongan khususnya pada musim kurang produktif (sekitar bulan September), sedangkan pada musim produktif (sekitar bulan Mei) dapat mengombinasikan antara E. denticulatum dan K. alvarezii. Untuk kawasan pesisir Pulau Nusa Penida yang memiliki kesesuaian lahan yang lebih baik dapat menanam jenis $K$. alvarezii saja atau mengombinasikan antara dua jenis rumput laut tersebut.

Melihat potensi kawasan yang ada, alternatif pengembangan budidaya rumput laut yang ada dapat dikombinasikan dengan komoditas lainnya yang dikenal dengan model budidaya secara terintegrasi (Soto, 2009). Model ini mengombinasikan beberapa spesies yang saling menguntungkan. Sebagai contoh adalah budidaya rumput laut dengan abalon. Di mana rumput laut yang dibudidayakan dapat dijadikan makanan untuk abalon, yang memiliki harga pasar yang lebih tinggi. Budidaya secara terintegrasi antara rumput laut $E$. denticulatum dan abalon (Haloitis squamata) telah dikaji di dua lokasi pengembangan: Desa Batu Nunggul dan Nusa Ceningan (Anonim, 2013). Hasil dari penelitian tersebut menunjukkan bahwa budidaya terintegrasi antara rumput laut dan abalon dapat meningkatkan produksi sampai $89,90 \%$; dibandingkan dengan hanya melakukan budidaya rumput laut saja (monoculture). Jenis lainnya yang mungkin bisa digunakan di kawasan ini adalah teripang. Model budidaya terintegrasi ini tentunya dapat diterapkan sesuai dengan aturan tata ruang yang ada sehingga dalam pelaksanaan ke depan tidak terjadi konflik kepentingan antar pengguna kawasan pesisir. Hal positif lainnya adalah adanya alternatif hasil yang tidak tertumpu sepenuhnya pada rumput laut, namun bisa menghasilkan dari biota budidaya lainnya.

Perspektif tingkat keberlanjutan usaha budidaya rumput laut juga telah dikaji secara komprehensif (Suryawati \& Radiarta, 2013). Tingkat keberlanjutan usaha budidaya rumput laut berdasarkan aspek ekologi, ekonomi, sosial, teknologi, dan hukum-kelembagaan, menunjukkan bahwa pengembangan usaha budidaya rumput laut di Nusa Penida secara multidimensi "cukup berkelanjutan" dengan nilai indeks keberlanjutan sebesar 51,21. Status keberlanjutan tersebut mengindikasikan bahwa pengembangan usaha budidaya rumput laut di Nusa Penida dapat berkembang menjadi usaha ekonomi produktif yang dapat diandalkan dan berkelanjutan.

\section{KESIMPULAN}

Rumput laut merupakan komoditas penting untuk menopang tingkat perekonomian masyarakat di Nusa Penida. Lahan yang dimanfaatkan untuk budidaya rumput laut adalah lahan pasang surut yang umumnya hanya tersebar di pantai Utara Pulau Nusa Penida dan Pulau Nusa Lembongan, serta pantai Barat Pulau Nusa Ceningan. Aktivitas budidaya rumput laut ini sangat bergantung pada kondisi iklim dan kualitas perairan yang berhubungan dengan pola musim tanam. Hasil penelitian ini menunjukkan bahwa tingkat kesesuaian lahan bulan Mei lebih besar (sangat sesuai $463 \mathrm{ha}$ ) dibandingkan pada bulan September (sangat sesuai 231 ha). Kawasan di Pulau Nusa Lembongan dan Nusa Ceningan merupakan kawasan yang lebih sensitif terhadap perubahan lingkungan perairan yang ditunjukkan dengan perubahan tingkat kesesuaian lahannya. Kawasan ini direkomendasikan untuk lebih membudidayakan jenis E. denticulatum. Alternatif berupa budidaya terintegrasi merupakan langkah yang dapat ditempuh untuk menyiasati pola musim tanam yang ada. Melalui budidaya terintegrasi ini secara nyata dapat meningkatkan produksi budidaya.

\section{UCAPAN TERIMA KASIH}

Penulis mengucapkan terima kasih kepada I Nyoman Landep dan Udjiana, pengurus kelompok pembudidaya rumput laut di Nusa Penida, dan tim survai kawasan dari Universitas Udayana: Dwi Budi Wiyanto, M.Si., Rahman, M.Si., dan Mohan atas bantuannya selama pengumpulan data lapangan. Kami juga mengucapkan terima kasih kepada tim kawasan Pusat Penelitian dan Pengembangan Perikanan Budidaya: Dr. Idil Ardi, Johan Risandy, M.Sc. Penelitian ini dibiayai dari DIPA Pusat Penelitian 
dan Pengembangan Perikanan Budidaya T.A 2013.

\section{DAFTAR ACUAN}

Anonim. 2013. Pengembangan budidaya rumput laut dan abalon secara terintegrasi untuk mendukung penerapan konsep blue economy di Nusa Penida. Laporan Teknis. Pusat Penelitian dan Pengembangan Perikanan Budidaya. Jakarta, $25 \mathrm{hlm}$.

American Public Health Association (APHA). 2005. Standard methods for the examination of water and wastewater. $21^{\text {st }}$ Edition. American Water Works Association (AWWA)/ American Public Works Association/Water Environment Federation. Washington. USA, $1,368 \mathrm{pp}$.

Diharmi, A., Fardiaz, D., Andarwulan, N., \& Heruwati, E.S. 2011 . Karakteristik komposisi kimia rumput laut merah (Rhodophycea) Eucheuma spinosum yang dibudidayakan dari perairan Nusa Penida, Takalar, dan Sumenep. Berkala Perikanan Terubuk, 39: 61-66.

Direktorat Jenderal Perikanan Budidaya (DJPB). 2012. Statistik perikanan budidaya Indonesia. Statprod No. 13. Kementerian Kelautan dan Perikanan. Jakarta, $116 \mathrm{hlm}$.

Dinas Peternakan, Perikanan dan Kelautan (DPPK). 2001. Profil budidaya rumput laut. Proyek Pengembangan Rumput Laut di Kecamatan Nusa Penida, Kabupaten Klungkung. $40 \mathrm{hlm}$.

GESAMP (IMO/FAO/Unesco-IOC/WMO/WHO/ IAEA/UN/UNEP Joint Group of Experts on the Scientific Aspects of Marine Environmental Protection). 2001. Planning and management for sustainable coastal aquaculture development. FAO Rep. Stud. GESAMP No. 68.90 pp.

Handa, A., Forbord, S., Wang, X., Broch, O.J., Dahle, S.W., Storseth, T.R., Reitan, K.I., Olsen, Y., \& Skjermo, J. 2013. Seasonal-and depth-dependent growth of cultivated kelp (Saccharina latissima) in close proximity to salmon (Salmo salar) aquaculture in Norway. Aquaculture, 414-415: 191-201.

Kapetsky, J.M. 2000. Present applications and future needs of meteorological and climatological data in inland fisheries and aquaculture. Agricultural and Forest Meteorology, 103: 109-117.

Kementerian Kelautan dan Perikanan (KKP). 2011 . Kelautan dan perikanan dalam angka 2011 . Pusat Data Statistik dan Informasi.
$122 \mathrm{hlm}$.

Kementerian Kelautan dan Perikanan (KKP). 2014. Blue economy pembangunan kelautan dan perikanan berkelanjutan untuk kesejahteraan masyarakat. $137 \mathrm{hlm}$.

Kementerian Lingkungan Hidup (KLH). 2004. Keputusan Menteri Negara Kependudukan dan Lingkungan Hidup No. 51 tahun 2004, tanggal 8 April 2004 tentang baku mutu air laut. Kementerian Lingkungan Hidup. Jakarta, $11 \mathrm{hlm}$.

Luxton, D. 1999. Potential for eucheuma "cottonii" seaweed farming in Samoa. South Pacific Aquaculture Development Project (Phase II) Food and Agriculture Organization of the United Nations (GCP/RAS/ 1 16/JPN). (http://www.fao.org/docrep/ 005 /AC 888E/AC 888E00.htm\#TOC). Disadur tanggal 1 Desember 2010.

Malczewski, J. 2000. On the use of weighted linear combination method in GIS: common and best practice approach. Transaction in GIS, 4: 5-22.

Malczewski, J. 1999. GIS and multicriteria decision analysis. John Wiley \& Sons. New York, $392 \mathrm{pp}$.

Marinho-Soriano, E., Fonseca, P.C., Carneiro, M.A.A., \& Moreira, W.S.C. 2006. Seasonal variation in the chemical composition of two tropical seaweeds. Bioresources Technology, 97: 2,402-2,406.

Morain, S. 1999. GIS solution in natural resources management: balancing the technical-political equation. On world press. USA, $361 \mathrm{pp}$.

Mubarak, H., Ilyas, S., Ismail, E., Wahyuni, I.S., Hartati, S.H., Pratiwi, E., Jangkaru, Z., \& Arifuddin, R. 1990. Petunjuk teknis budidaya rumput laut. Badan Litbang Pertanian, Puslitbang Perikanan. IDRC, Infish. $93 \mathrm{hlm}$.

Parenrengi, A., Rachmansyah, \& Suryati, E. 2011. Budidaya rumput laut penghasil karaginan (Karaginofit). Edisi Revisi. Balai Riset Perikanan Budidaya Air Payau, Badan Penelitian dan Pengembangan Kelautan dan Perikanan, Kementerian Kelautan dan Perikanan. Jakarta, $54 \mathrm{hlm}$.

Radiarta, I N., Erlania, \& Rusman. 2013. Pengaruh iklim terhadap musim tanam rumput laut, Kappaphycus alvarezii, di Teluk Gerupuk Kabupaten Lombok Tengah, Nusa Tenggara Barat. J. Ris. Akuakultur, 8(3): 453-464.

Radiarta, I N., Saputra, A., \& Albasri, H. 2012. Pemetaan kelayakan lahan budidaya rumput laut (Kappaphycus alvarezii) di Kabupaten 
Bintan Provinsi Kepulauan Riau dengan pendekatan sistem informasi geografis dan penginderaan jauh. J. Ris. Akuakultur, 7(1): 145-157.

Radiarta, I N., Saitoh, S-I., \& Miyazono, A. 2008. GIS-based multi-criteria evaluation models for identifying suitable sites for Japanese scallop (Mizuhopecten yessoensis) aquaculture in Funka Bay, Southwestern Hokkaido, Japan. Aquaculture, 284: 127135.

Saaty, T.L. 1977. A scaling method for priorities in hierarchical structures. Journal of Mathematical Psychology, 15: 234-281.

Sobari, M.P. 1993. Skala usaha dan efisiensi ekonomi relatif usaha tani rumput laut. Buletin Ekonomi Perikanan, 1: 12-26.

Soto, D. (Ed.). 2009. Integrated mariculture: a global review. FAO Fisheries and Aquaculture Technical Paper. No. 529. Rome, FAO. 183 pp.

Suryawati, S.H. \& Radiarta, I N. 2013. Analisa sosial ekonomi kelembagaan dan status keberlanjutan pengembangan usaha budidaya rumput laut di Nusa Penida.
Analisis Kebijakan Pembangunan Perikanan Budidaya 2013 (inpress).

Sulistijo \& Nontji, A. 1995. Potensi lingkungan laut untuk kegiatan budidaya. Sudradjat et al. (penyunting). Prosiding Temu Usaha Pemasyarakatan Teknologi Keramba Jaring Apung Bagi Budidaya Laut. Jakarta, 12-13 April 1995. Pusat Penelitian dan Pengembangan Perikanan, Badan Litbang Pertanian bekerja sama dengan Forum Komunikasi Penelitian dan Pengembangan Agribisnis. hlm. 54-68.

Tiensongrusmee, B. 1990. Site selection for Eucheuma spp. farming. UNDP/FAO Regional Seafarming Development and Demonstration Project (RAS/90/002). Kasetsart University Campus, Bangkok, Thailand. (http://www.fao.org/docrep/field/003/ AB738E/AB738E00.htm\#TOC). Disadur tanggal 30 November 2010.

Welly, M., Sanjaya, W., Trimudya, D., \& Yanto, W.G. 2011 . Profil perikanan Nusa Penida, Kabupaten Klungkung Provinsi Bali. Kerja sama Pemda Kabupaten Klungkung Coral Triangle Center (CTC) dan Sekolah Tinggi Perikanan (STP). Jakarta, $32 \mathrm{hlm}$. 